

Fabian Dorsch

The Unity of Imagining 
Philosophische Forschung Philosophical Research

Herausgegeben von / Edited by

Johannes Brandl $\bullet$ Andreas Kemmerling

Wolfgang Künne • Mark Textor

Band 9 / Volume 9 
Fabian Dorsch

\section{The Unity of Imagining}

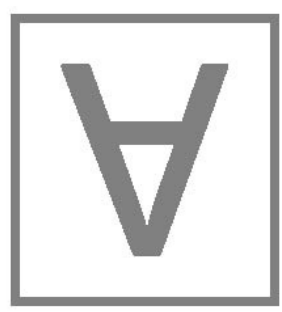

\section{ontos \\ verlag}


Bibliographic information published by the Deutsche Nationalbibliothek

The Deutsche Nationalbibliothek lists this publication in the Deutsche Nationalbibliographie; detailed bibliographic data is available in the Internet at http://dnb.ddb.de

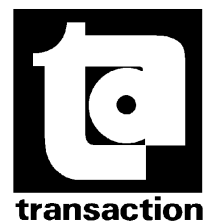

\author{
North and South America by \\ Transaction Books \\ Rutgers University \\ Piscataway, NJ 08854-8042 \\ trans@transactionpub.com
}

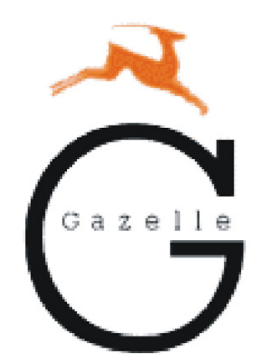

United Kingdom, Ireland, Iceland, Turkey, Malta, Portugal by

Gazelle Books Services Limited

White Cross Mills

Hightown

LANCASTER, LA1 4XS

sales@gazellebooks.co.uk

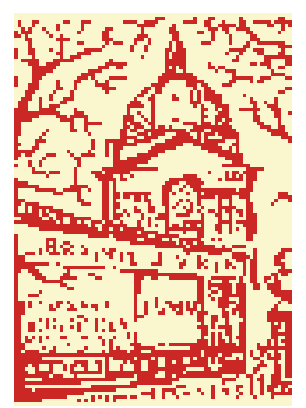

Livraison pour la France et la Belgique:

Librairie Philosophique J.Vrin

6 , place de la Sorbonne ; F-75005 PARIS

Tel. +33 (0)1 43540347 ; Fax +33 (0)1 43544818

www.vrin.fr

${ }^{\circ} 2012$ ontos verlag

P.O. Box 15 41, D-63133 Heusenstamm

www.ontosverlag.com

ISBN: 978-3-86838-174-0

2012

No part of this book may be reproduced, stored in retrieval systems or transmitted in any form or by any means, electronic, mechanical, photocopying, microfilming, recording or otherwise without written permission from the Publisher, with the exception of any material supplied specifically for the purpose of being entered and executed on a computer system, for exclusive use of the purchaser of the work

Printed on acid-free paper

ISO-Norm 970-6

FSC-certified (Forest Stewardship Council)

This hardcover binding meets the International Library standard

Printed in Germany

by $\mathrm{CPI}$ buch bücher.de $\mathrm{GmbH}$ 